DOI: https://doi.org/10.24127/ajpm.v10i4.4099

\title{
KEMAMPUAN MAHASISWA DALAM MENYELESAIKAN SOAL TIPE HOTS PADA MATA KULIAH KAPITA SELEKTA MATEMATIKA SMA
}

\author{
Allen Marga Retta ${ }^{1}$, Nila Kesumawati ${ }^{2 *}$, Dina Octaria ${ }^{3}$ \\ ${ }^{1,2 * 3}$ Pendidikan Matematika, Universitas PGRI Palembang, Indonesia \\ ${ }^{*}$ Corresponding author. \\ E-mail: $\quad$ allenmargaretta1@gmail.com $^{\text {l) }}$ \\ nilakesumawati@univpgri-palembang.ac.id ${ }^{2 *}$ \\ dinaoktaria@gmail.com ${ }^{3)}$
}

Received 07 August 2021; Received in revised form 16 November 2021; Accepted 15 December 2021

\begin{abstract}
Abstrak
Penelitian ini bertujuan untuk mendeskripsikan kemampuan mahasiswa dalam menyelesaikan soal tipe Higher Order Thinking Skills (HOTS) pada mata kuliah Kapita Selekta Matematika SMA. Subjek penelitian ini yaitu mahasiswa Program Studi Pendidikan Matematika yang mendapat mata kuliah Kapita Selekta Matematika SMA tahun ajar 2020/2021. Penelitian ini merupakan penelitian deskriptif dengan jumlah mahasiswa sebanyak 26 orang. Data hasil tes dianalisis secara kuantitatif dan kualitatif. Data kuantitatif diperoleh dengan mendata jumlah mahasiswa yang dapat menjawab soal tipe HOTS (C4, C5, dan C6), kemudian dihitung persentasenya. Data kualitatif diperoleh dengan menganalisis hasil tes mahasiswa yang bersumber pada perspektif HOTS. Hasil penelitian menunjukkan secara keseluruhan kemampuan mahasiswa dalam menyelesaikan soal bertipe HOTS pada mata kuliah Kapita Selekta Matematika SMA mencapai 80,77\%, yang masuk pada kategori tinggi dalam mengerjakan soal tipe C4 (menganalisis), artinya mahasiswa mampu menguraikan suatu informasi terhadap suatu materi menjadi komponen-komponen yang lebih jelas. Selanjutnya diperoleh persentase sebesar 75,38\% juga termasuk dalam kategori tinggi dalam mengerjakan soal tipe C5 (mengevaluasi), artinya mahasiswa mampu melakukan penilaian atau evaluasi terhadap solusi yang disajikan sesuai standar yang ditentukan oleh mahasiswa sendiri. Terakhir diperoleh persentase sebesar 7,69\% dengan kategori sangat kurang dalam mengerjakan soal tipe C6 (mengkreasikan), artinya masih banyak mahasiswa belum mampu mengorganisasikan bagian-bagian menjadi struktur baru dengan tepat.
\end{abstract}

Kata kunci: Kapita selekta matematika SMA; kemampuan mahasiswa; soal tipe HOTS.

\begin{abstract}
This study aims to describe the student's ability to solve the Higher Order Thinking Skills (HOTS) problem in the High School Mathematics Capita Selecta subject. The subjects of this study were students of the Mathematics Education Study Program who received the subject for the 2020/2021 academic year. This research is a descriptive study with 26 students. Test results were analyzed quantitatively and qualitatively. Quantitative data were obtained by recording the number of students who could answer HOTS-type questions (C4, C5, and C6), then the percentage was calculated. Qualitative data were obtained by analyzing student test results from the HOTS perspective. The results showed that the overall, the students' ability to solve HOTS-type questions in the Kapita Selekta Mathematics course for SMA reached 80.77\%, which was included in the high category in working on type C4 questions (analyzing), meaning that students were able to decipher information on a material into clearer components. Furthermore, the percentage of $75.38 \%$ is also included in the high category in working on type C5 questions (evaluating), meaning that students are able to make an assessment or evaluation of the solutions presented according to the standards set by the students themselves. Finally, a percentage of $7.69 \%$ was obtained with a very poor category in working on type C6 questions (creating), meaning that there are still many students who have not been able to properly organize the parts into a new structure.
\end{abstract}

Keywords: Capita selecta mathematics for high school; HOTS-type problem; student ability.

This is an open access article under the Creative Commons Attribution 4.0 International License 
DOI: https://doi.org/10.24127/ajpm.v10i4.4099

\section{PENDAHULUAN}

Matematika memainkan peranan yang sangat penting dalam memecahkan masalah kehidupan sehari-hari. Banyak mahasiswa yang tidak bisa menggunakan kemampuan matematis yang telah mereka miliki, bahkan tidak bisa menggunakan kemampuan tersebut untuk menyelesaikan suatu masalah matematis jika diberikan masalah yang sedikit berbeda dari apa yang telah mereka pelajari (Budiman \& Jailani, 2014). Hal tersebut ditunjukan dalam penelitian (Bona, 2018) bahwa kemampuan peserta didik dalam memecahkan masalah matematis tidak jauh berbeda antara tingkat SD dan SMA. Ditambah pula dengan hasil PISA, Indonesia berada dirangking 74 dari 79 negara pada tahun 2018 dengan skor rata-rata 379 yang menunjukan bahwa tidak ada perkembangan yang signifikan dari tahun 2015 yang mendapatkan rangking 65 dari 72 negara dengan skor 386 bahkan hasil PISA menunjukan terjadi penurunan skor dari tahun 2015 ke tahun 2018. Tidak hanya hasil PISA yang menunjukan tidak ada perkembangan yang signifikan tetapi juga hasil TIMMS menunjukan hal yang sama yaitu Indonesia berada pada tingkat rendah dengan skor 397 (dibawah 400) pada tahun 2015 (Hadi \& Novaliyosi, 2019). Hasil penelitian (Prasetyo, 2020) menunjukan bahwa kemampuan peserta didik Indonesia hanya mampu menyelesaikan soal matematika sederhana. Sedangkan untuk bersaing dengan negara lain peserta didik dituntut untuk dapat menyelesaikan soal matematika yang kompleks artinya peserta didik harus memiliki kemampuan dengan daya pikir berlevel tinggi. Oleh karena itu, untuk meningkatkan kemampuan matematis, pemerintah Indonesia menerapkan
Higher Order Thinking Skills (HOTS) dengan merevisi kurikulum 2013 yang bertujuan mengkondisikan peserta didik untuk dapat berpikir logis, kritis, sistematis dan memiliki kemampuan dengan daya pikir berlevel tinggi (Destiniar et al., 2020; Suryapuspitarini et al., 2018)

HOTS merupakan level berpikir tertinggi dalam hirarki kognitif yang memungkinkan peserta didik dalam mengolah informasi secara efektif dan efisien (Yee et al., 2015; Yen \& Halili, 2015). HOTS juga dapat meningkatkan kemampuan matematis sehingga peserta didik mampu berpikir kritis dan kreatif melalui permasalahan yang diberikan berupa soal berbasis HOTS yang bertujuan untuk memacu pemahaman peserta didik lebih mendalam (Apino \& Retnawati, 2017; Dinni, 2018; Listiani \& Sulistyorini, 2020; Wulandari et al., 2020). Oleh sebab itu, HOTS memegang peran penting dalam meningkatkan efektivitas proses pembelajaran dan dapat mengantarkan peserta didik pada kesuksesan (Tanujaya et al., 2017). Tolak ukur keberhasilan proses pembelajaran berdasarkan dimensi proses kognitif dibedakan dalam enam tingkatan yaitu mengingat (C1), memahami (C2), mengaplikasikan (C3), menganalisis (C4), mengevaluasi (C5), serta mengkreasi (C6) atau lebih dikenal dengan taksonomi bloom yang direvisi oleh Anderson dan Krathwohl (Brookhart, 2010; Churches, 2007; Forehand, 2005).

Kemampuan berpikir seseorang terbagi menjadi dua tingkatan yaitu Lower Order Thinking Skills (LOTS) dan Higher Order Thinking Skills (HOTS). LOTS mencakup kemampuan $\mathrm{C} 1, \mathrm{C} 2$, dan $\mathrm{C} 3$ sedangkan HOTS mencakup kemampuan C4, C5, dan C6 (Suryapuspitarini et al., 2018). 
Walaupun kemampuan C1, C2, dan C3 termasuk dalam LOTS namun sangat berpengaruh terhadap HOTS (Wicasari, B., \& Ernaningsih, 2016). Sejalan dengan (Dosinaeng et al., 2019) menyatakan bahwa kemampuan $\mathrm{C} 1$, C2, dan C3 merupakan dasar untuk membentuk HOTS seseorang.

Sebagai calon pendidik, mahasiswa harus terbiasa dengan soal yang bertipe HOTS, sehingga ketika akan memasuki dunia kerja akan lebih mudah untuk menerapkan ilmunya terkhusus untuk menyelesaikan soal bertipe HOTS. Mata kuliah kapita selekta matematika SMA merupakan mata kuliah wajib yang sangat penting untuk dipelajari mahasiswa sebagai calon pendidik, karena dalam mata kuliah ini membahas secara mendalam mengenai aljabar dan geometri di sekolah menengah atas. Oleh karena itu, pengaplikasian soal HOTS sangat tepat diterapkan pada mata kuliah ini.

Berdasarkan pengalaman selama mengajar mata kuliah Kapita Selekta Matematika SMA terdapat beberapa kendala selama proses pembelajaran yaitu 1) masih minimnya buku ajar Kapita Selekta Matematika SMA yang berorientasi pada HOTS, sehingga perlunya analisis yang mendalam terkait sudah sampai sejauh mana mahasiswa memahami soal-soal HOTS, 2) belum terbiasanya mahasiswa mengerjakan soal HOTS sehingga menyebabkan mahasiswa kesulitan dalam memecahkan masalah ketika dihadapkan dengan soal yang bertipe $\mathrm{C} 4, \mathrm{C} 5$, dan C6. Hal ini sejalan dengan (Sangpom et al., 2016), peserta didik terbiasa diajarkan dengan metode ceramah, pemberian rumus dan hafalan. Hasil penelitian lain juga menyatakan bahwa peserta didik menganggap soal HOTS sulit untuk diselesaikan (Abdullah et al., 2015; C. Chinedu C. \& Kamin, 2015). Hal ini karena selama pembelajaran di kelas, peserta didik jarang diajarkan untuk menyelesaikan soal HOTS (Wulandari et al., 2020).

Beberapa penelitian sebelumnya menunjukan bahwa terdapat kekeliruan yang terjadi secara terus menerus tanpa disadari dalam sistem Pendidikan, khususnya dalam pembelajaran matematika, antara lain: (1) buku teks dan LKS yang digunakan tidak mengembangkan HOTS peserta didik (Siswono, 2018), (2) Terdapat kesalahan dalam memahami apa yang dimaksud dengan soal HOTS (Tanujaya \& Mumu, 2020), 3) Masih kurangnya kemampuan pendidik dalam menyusun dan menguasai soal HOTS sehingga belum bisa diterapkan dalam proses pembelajaran (Awaliyah, 2018).

Menyikapi permasalahan di atas, sebagai calon pendidik, penguasaan HOTS yang baik, perlu dimiliki oleh mahasiswa agar mampu mengajarkan para siswanya dalam menyelesaikan soal HOTS. Oleh sebab itu, artikel ini difokuskan pada bagaimana kemampuan mahasiswa dalam menyelesaikan soal tipe HOTS pada mata kuliah kapita selekta matematika SMA yang bertujuan untuk mendeskripsikan kemampuan mahasiswa dalam menyelesaikan soal HOTS pada mata kuliah Kapita Selekta Matematika SMA.

\section{METODE PENELITIAN}

Penelitian ini merupakan penelitian deskriptif yang bertujuan untuk memahami fenomena tentang apa yang dialami oleh subjek penelitian. Penelitian ini dilakukan pada mahasiswa program studi Pendidikan Matematika Universitas PGRI Palembang tahun ajar 2020/2021 dengan jumlah 26 mahasiswa yang menempuh mata kuliah kapita selekta matematika SMA. Teknik pengumpulan 
DOI: https://doi.org/10.24127/ajpm.v10i4.4099

data berdasarkan definisi sesuai taksonomi Bloom yang telah direvisi oleh (Anderson et al., 2001) yang mencakup kemampuan pada level berpikir tingkat tinggi mulai dari $\mathrm{C} 4$, C5, hingga C6. Instrumen dalam penelitian ini adalah soal tes tipe HOTS berupa tes uraian.

Analisis yang digunakan adalah analisis deskriptif yang dilakukan secara kuantitatif dan kualitatif. Data kuantitatif diperoleh dengan mendata jumlah mahasiswa yang dapat menjawab soal tipe HOTS (C4, C5, dan C6) berdasarkan indikator penskoran, kemudian dihitung persentasenya. Berikut Tabel 1 menyajikan indikator kemampuan berpikir tingkat tinggi.

Tabel 1. Indikator kemampuan berpikir tingkat tinggi

\begin{tabular}{|c|c|c|c|}
\hline No & $\begin{array}{c}\text { Tingkat Kemampuan } \\
\text { Kognitif }\end{array}$ & Skor & Indikator \\
\hline \multirow[t]{5}{*}{1} & C4 (menganalisis) & 4 & $\begin{array}{l}\text { Mampu menguraikan informasi dengan tepat } \\
\text { dan menghubungkan keterkaitan informasi } \\
\text { serta dapat menyelesaikan permasalahan } \\
\text { dengan langkah penyelesaian yang tepat. }\end{array}$ \\
\hline & & 3 & $\begin{array}{l}\text { Mampu menguraikan informasi dengan tepat, } \\
\text { dan menghubungkan keterkaitan informasi, } \\
\text { serta dapat menyelesaikan permasalahan } \\
\text { dengan langkah penyelesaian yang hampir } \\
\text { tepat }\end{array}$ \\
\hline & & 2 & $\begin{array}{l}\text { Mampu menguraikan informasi dengan tepat, } \\
\text { dan menghubungkan keterkaitan informasi, } \\
\text { namun belum menyelesaikan permasalahan } \\
\text { dengan langkah penyelesaian yang tepat }\end{array}$ \\
\hline & & 1 & $\begin{array}{l}\text { Belum mampu menguraikan informasi } \\
\text { dengan tepat, dan menghubungkan } \\
\text { keterkaitan informasi, sehingga langkah } \\
\text { penyelesaian tidak tepat }\end{array}$ \\
\hline & & 0 & $\begin{array}{l}\text { Tidak mampu melakukan analisis sama } \\
\text { sekali. }\end{array}$ \\
\hline \multirow[t]{5}{*}{2} & C5 (mengevaluasi) & 4 & $\begin{array}{l}\text { Mampu melakukan penilaian terhadap solusi } \\
\text { dengan tepat dan dapat memberikan } \\
\text { kesimpulan yang tepat. }\end{array}$ \\
\hline & & 3 & $\begin{array}{l}\text { Mampu melakukan penilaian terhadap solusi } \\
\text { dengan tepat, namun tidak memberikan } \\
\text { kesimpulan yang tepat }\end{array}$ \\
\hline & & 2 & $\begin{array}{l}\text { Kurang mampu melakukan penilaian terhadap } \\
\text { solusi dengan tepat, sehingga belum } \\
\text { memberikan kesimpulan yang tepat }\end{array}$ \\
\hline & & 1 & $\begin{array}{l}\text { Tidak mampu melakukan penilaian terhadap } \\
\text { solusi dengan tepat, namun jawaban hampir } \\
\text { mengarah ke penyelesaian yang tepat. }\end{array}$ \\
\hline & & 0 & $\begin{array}{l}\text { Tidak mampu melakukan penilaian terhadap } \\
\text { solusi sama sekali. }\end{array}$ \\
\hline
\end{tabular}


DOI: https://doi.org/10.24127/ajpm.v10i4.4099

\begin{tabular}{|c|c|c|c|}
\hline No & $\begin{array}{c}\text { Tingkat Kemampuan } \\
\text { Kognitif }\end{array}$ & Skor & Indikator \\
\hline \multirow[t]{5}{*}{3} & C6 (mengkreasi) & 4 & $\begin{array}{l}\text { Mampu membuat generalisasi dan merancang } \\
\text { suatu cara untuk menyelesaikan masalah serta } \\
\text { mengorganisasikan informasi menjadi strategi } \\
\text { yang tepat. }\end{array}$ \\
\hline & & 3 & $\begin{array}{l}\text { Mampu membuat generalisasi dan merancang } \\
\text { suatu cara untuk menyelesaikan masalah serta } \\
\text { mengorganisasikan informasi menjadi strategi } \\
\text { yang hampir tepat atau masih terdapat sedikit } \\
\text { kesalahan dalam menuliskan jawaban. }\end{array}$ \\
\hline & & 2 & $\begin{array}{l}\text { Mampu membuat generalisasi dan merancang } \\
\text { suatu cara untuk menyelesaikan masalah } \\
\text { namun belum mampu mengorganisasikan } \\
\text { informasi menjadi strategi yang tepat. }\end{array}$ \\
\hline & & 1 & $\begin{array}{l}\text { Belum mampu membuat generalisasi dan } \\
\text { merancang suatu cara untuk menyelesaikan } \\
\text { masalah dan mengorganisasikan informasi } \\
\text { dengan tepat, namun rancangan jawaban } \\
\text { hampir mengarah ke penyelesaian yang tepat. }\end{array}$ \\
\hline & & 0 & $\begin{array}{l}\text { Tidak mampu membuat generalisasi dan } \\
\text { merancang suatu cara untuk menyelesaikan } \\
\text { masalah serta mengorganisasikan informasi } \\
\text { menjadi strategi sama sekali. }\end{array}$ \\
\hline
\end{tabular}

Data kualitatif diperoleh dengan cara menganalisis jawaban tes mahasiswa berdasarkan perspektif HOTS. Setelah itu, dilakukan analisis sesuai dengan aspek-aspek yang terdapat pada HOTS (C4, C5, dan C6). Analisis kemampuan mahasiswa dalam menyelesaikan soal HOTS dilakukan dengan cara mengelompokkan ke dalam lima kategori yang disajikan pada Tabel 2 (Ngalim \& Purwanto., 2012).

Tabel 2. Kategori kemampuan berpikir tingkat tinggi mahasiswa

\begin{tabular}{cc}
\hline Presentase & Kategori \\
\hline$X \geq 87,5 \%$ & Sangat Tinggi \\
$75 \% \leq X<87,5 \%$ & Tinggi \\
$62,5 \% \leq X<75 \%$ & Cukup \\
$50 \% \leq X<62,5 \%$ & Kurang \\
$X<50 \%$ & Sangat Kurang \\
\hline
\end{tabular}

\section{HASIL DAN PEMBAHASAN}

Penelitian ini dilakukan dengan memberikan soal tipe HOTS yaitu soal C4, C5, dan C6 kepada 26 mahasiswa Program Studi Pendidikan Matematika yang mendapat mata kuliah kapita selekta matematika SMA. Berikut hasil analisis kategori mahasiswa dalam menyelesaikan 10 soal tipe HOTS pada mata kuliah Kapita Selekta Matematika disajikan pada Tabel 3 .

Tabel 3. Kategori HOTS mahasiswa program studi pendidikan matematika

\begin{tabular}{ccc}
\hline Tingkat Kognitif & Presentase & $\begin{array}{c}\text { Kategori } \\
\text { HOTS }\end{array}$ \\
\hline Menganalisis (C4) & $80,77 \%$, & Tinggi \\
Mengevaluasi (C5) & $75,38 \%$, & Tinggi \\
Mengkreasi (C6) & $7,69 \%$. & Sangat Kurang \\
\hline
\end{tabular}

Berdasarkan Tabel 3, rata-rata presentase keseluruhan kemampuan mahasiswa dalam menyelesaikan 10 
DOI: https://doi.org/10.24127/ajpm.v10i4.4099

soal tipe HOTS pada aspek menganalisis (C4) sebesar 80,77\% yang termasuk dalam kategori tinggi, artinya mahasiswa mampu menguraikan informasi dengan tepat dan menghubungkan keterkaitan informasi serta dapat menyelesaikan permasalahan dengan langkah penyelesaian yang tepat. Selanjutnya penyelesaian soal pada aspek mengevaluasi (C5) rata-rata presentase keseluruhan kemampuan mahasiswa sebesar 75,38\% masih termasuk dalam kategori tinggi, artinya mahasiswa mampu melakukan penilaian terhadap solusi dengan tepat dan dapat memberikan kesimpulan yang tepat. Sedangkan untuk penyelesaian soal pada aspek mengkreasi (C6) rata-rata presentase keseluruhan kemampuan mahasiswa sebesar 7,69\% termasuk dalam kategori sangat kurang, artinya masih banyak mahasiswa yang tidak mampu membuat generalisasi dan merancang suatu cara untuk menyelesaikan masalah serta mengorganisasikan informasi menjadi strategi sama sekali. Contoh soal HOTS tipe C4, C5, dan C6 dapat dilihat pada Tabel 4.

Tabel 4 Contoh Soal HOTS Tipe C4, C5, dan C6.

\begin{tabular}{|c|c|c|}
\hline Tingkat Kognitif & $\begin{array}{c}\text { Nomor } \\
\text { Soal }\end{array}$ & Soal HOTS \\
\hline Menganalisis (C4) & 4 & $\begin{array}{l}\text { Seorang tukang kayu memiliki sebuah balok luas } \\
\text { alasnya } 96 \mathrm{~cm}^{2} \text {, luas sisi depannya adalah } 72 \\
\mathrm{~cm}^{2} \text {, dan luas sisi sampingnya adalah } 48 \mathrm{~cm}^{2} \text {. } \\
\text { Tentukan volume balok tersebut? }\end{array}$ \\
\hline Mengevaluasi (C5) & 1 & $\begin{array}{l}\text { Dua kapal yakni Baruna I dan Baruna II } \\
\text { berangkat dari pelabuhan Bakahuni pada waktu } \\
\text { yang bersamaan. Kedua kapal berlayar pada jalur } \\
\text { yang lurus dan membentuk sudut } 60^{\circ} \text { satu sama } \\
\text { lain. Jika kecepatan kapal Baruna I } 25 \mathrm{~km} / \mathrm{jam} \\
\text { dan kecepatan kapal Baruna II } 15 \mathrm{~km} / \mathrm{jam} \text {, } \\
\text { berapakah jarak antara kapal Baruna I dan kapal } \\
\text { Baruna II setelah berlayar } 1 \text { jam? }\end{array}$ \\
\hline Mengkreasi (C6) & 5 & Tentukan junlah deret berikut! \\
\hline
\end{tabular}

$$
\frac{1}{\sqrt{1}+\sqrt{2}}+\frac{1}{\sqrt{2}+\sqrt{3}}+\frac{1}{\sqrt{3}+\sqrt{4}}+\frac{1}{\sqrt{4}+\sqrt{5}}+\cdots+\frac{1}{\sqrt{99}+\sqrt{100}}=\cdots
$$

Berdasarkan Tabel 4, soal tipe C4 atau menganalisis merupakan kemampuan bagaimana mahasiswa dapat menguraikan suatu informasi terhadap suatu materi menjadi komponenkomponen yang lebih jelas dalam menemukan asumsi, membedakan pendapat, dan fakta serta menemukan hubungan sebab akibat. Menurut (Effendi, 2017) soal tipe C4 melibatkan proses menguraikan suatu permasalahan dengan mengaitkan unsur-unsur penyusun dengan strukturnya besarnya. Hal ini ditunjukkan pada soal nomor 4 yang menuntut mahasiswa harus terlebih dahulu mengetahui mana alas, sisi depan dan sisi samping dari balok. Hal ini bertujuan untuk mendapatkan ukuran panjang, lebar dan tinggi pada balok dengan cara menguraikan informasi yang ada. Terdapat 24 dari 26 mahasiswa yang mampu menguraikan informasi dengan tepat, dan menghubungkan keterkaitan informasi 
serta dapat menyelesaikan permasalahan dengan langkah penyelesaian yang tepat (presentase 92,31\%) tergolong dalam kategori sangat tinggi. Dapat disimpulkan bahwa kemampuan mahasiswa dalam menyelesaikan soal
HOTS tipe C4 yaitu pada aspek menganalisis dapat dikatakan sudah baik. Berikut Gambar 1 menyajikan hasil jawaban mahasiswa $\mathrm{ZH}$ pada soal HOTS bertipe C4.

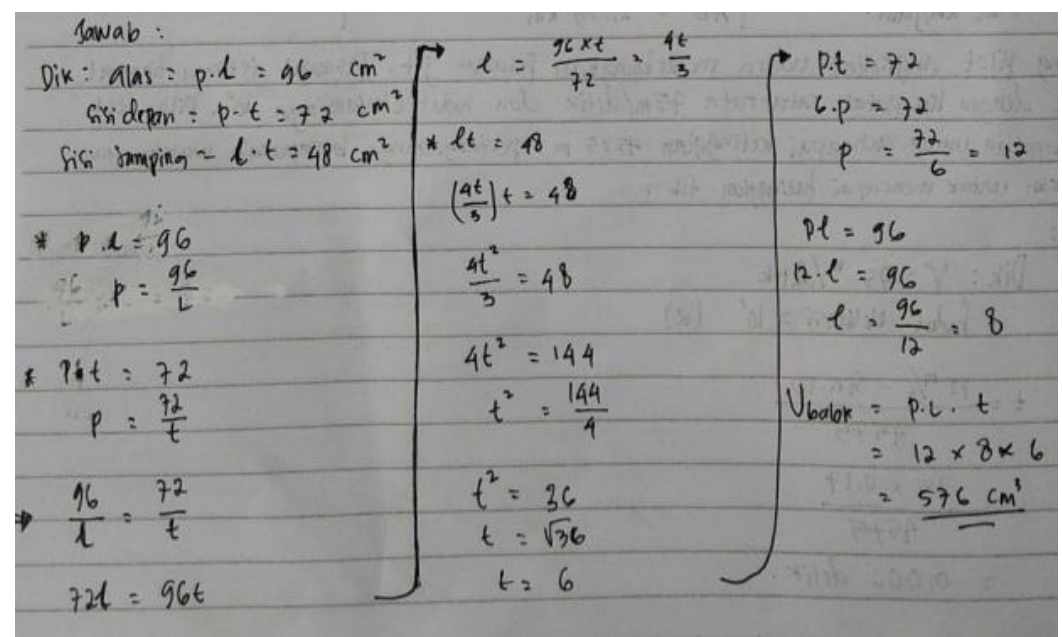

Gambar 1. Hasil jawaban mahasiswa ZH pada soal HOTS bertipe C4.

Berdasarkan Gambar 1 mahasiswa $\mathrm{ZH}$ telah menguraikan informasi yang ada pada soal yaitu dengan menguraikan luas alas balok yang merupakan hasil perkalian antara panjang dan lebar, menguraikan luas sisi depan balok yang merupakan hasil perkalian antara panjang dan tinggi balok, dan menguraikan luas sisi samping yang merupakan perkalian antara lebar dan tinggi. Setelah diuraikan mahasiswa $\mathrm{ZH}$ menghubungkan atau mengaitkan informasi yang ada dengan cara mensubstitusi maka diperoleh ukuran panjang, lebar dan tinggi balok. Sehingga volume balok dapat ditentukan dengan mengalikan antara ukuran panjang, lebar dan tinggi dan hasilnya adalah $576 \mathrm{~cm}^{3}$. Selanjutnya terdapat cara lain yang digunakan mahasiswa OS dalam mencari ukuran panjang, lebar dan tinggi balok. Hasil jawaban mahasiswa OS pada soal bertipe $\mathrm{C} 4$ dapat dilihat pada Gambar 2.

$$
\begin{array}{llr}
P \times L=96 & (P \times L)(P \times T)=96 \times 72 & \text { Vbolef }=12 \times 8 \times 6 \\
P \times T=72 & =576 \mathrm{~cm}^{3} \\
L \times T=46 & (P \times P \times L \times T)=6912 & \\
1 & \frac{(P \times P \times L \times T)}{(L \times T)}=\frac{6912}{48}=144 \\
& P=144 \\
P=12 \\
L=\frac{96}{12}=8 \\
T=\frac{72}{12}=6
\end{array}
$$

Gambar 2. Hasil jawaban mahasiswa OS pada soal HOTS bertipe C4.

Berdasarkan Gambar 2, OS menggunakan cara lain dalam memperoleh ukuran panjang, lebar dan tinggi balok yaitu dengan mengeliminasi variabel yang ada dan mensubstitusi ukuran yang diperoleh melalui hasil eliminasi, sehingga menghasilkan hasil yang sama yaitu volume balok adalah $576 \mathrm{~cm}^{3}$. Selanjutnya Gambar 3 menyajikan hasil jawaban mahasiswa FPA yang menggunakan proses yang lebih cepat dalam menyelesaikan permasalahan yang disajikan. 
DOI: https://doi.org/10.24127/ajpm.v10i4.4099

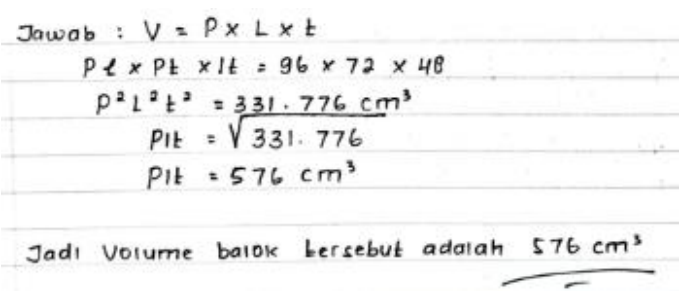

Gambar 3. Hasil jawaban mahasiswa

FPA pada soal HOTS bertipe C4

Berdasarkan Gambar 3, mahasiswa FPA dapat menyelesaikan permasalahan menentukan volume balok yang diketahui ukuran dari sisi alas, sisi depan dan sisi samping balok. Mahasiswa FPA menggunakan cara yang cukup sederhana dengan mengalikan seluruh ukuran sisi alas, sisi depan dan sisi samping balok dengan tetap memperhatikan konsep luas sisi alas, sisi depan dan sisi samping balok sehingga diperoleh volume balok adalah $576 \mathrm{~cm}^{3}$. Proses menghasilkan volume balok lebih cepat dibanding dengan jawaban mahasiswa $\mathrm{ZH}$ dan OS.

Selanjutnya soal tipe C5 atau mengevaluasi mahasiswa dituntut untuk memeriksa dan mengkritisi suatu pernyataan berdasarkan pada kriteria dan standar yang telah ditetapkan. Menurut (Krathwohl, 2002) soal tipe C5 atau mengevaluasi yakni bagaimana cara mahasiswa melakukan penilaian terhadap solusi yang disajikan untuk memastikan kualitas, efektivitas, efisiensi dan konsistensi sesuai dengan standar yang dapat ditentukan oleh mahasiswa sendiri. Hal ini ditunjukkan pada soal nomor 1 yang menuntut mahasiswa untuk membuat suatu penilaian setelah menghitung jarak kapal Baruna I dan Baruna II dengan memberikan gambar ilustrasi terlebih dahulu untuk memudahkan dalam menyelesaikan permasalahan serta memadukan materi jarak dengan memanfaatkan materi trigonometri sehingga dapat diambil kesimpulan yaitu jarak kapal Baruna I dan Baruna II adalah $5 \sqrt{19} \mathrm{~km}$ atau $21,79 \mathrm{~km}$. Pada soal ini terdapat 10 mahasiswa yang menjawab benar dengan presentase $38,46 \%$ masuk dalam kategori sangat kurang, selanjutnya terdapat 16 mahasiswa yang belum tepat dalam memecahkan masalah pada soal tersebut. Hal ini memperlihatkan bahwa masih banyak mahasiswa yang belum mampu menyelesaikan soal HOTS tipe C5 yaitu pada aspek evaluasi. Berikut Gambar 4 hasil jawaban mahasiswa SP pada soal HOTS bertipe C5.

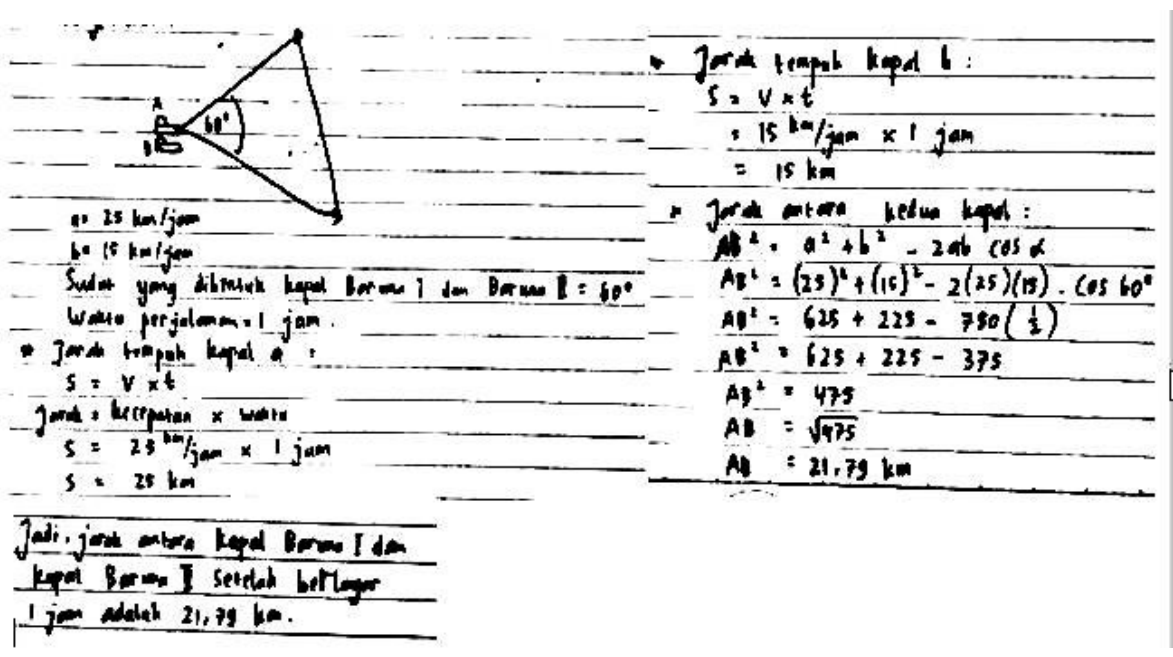

Gambar 4. Hasil Jawaban Mahasiswa SP pada soal HOTS bertipe C5 
DOI: https://doi.org/10.24127/ajpm.v10i4.4099

Berdasarkan Gambar 4, mahasiswa SP dapat menyelesaikan permasalahan yang disajikan pada soal tipe C5. Hal ini ditunjukan dengan mahasiswa telah melakukan penilaian terhadap solusi yang telah dibuat yaitu dengan memberikan kesimpulan bahwa jarak kapal Baruna I dan Baruna II adalah $5 \sqrt{19} \mathrm{~km}$ atau $21,79 \mathrm{~km}$. Untuk menjawab soal tipe C5 ini masih banyak mahasiswa yang tidak melakukan penilaian terhadap solusi yang telah dibuat. Berikut Gambar 5 hasil jawaban mahasiswa VT dalam menyelesaikan permasalahan yang disajikan pada soal tipe C5.

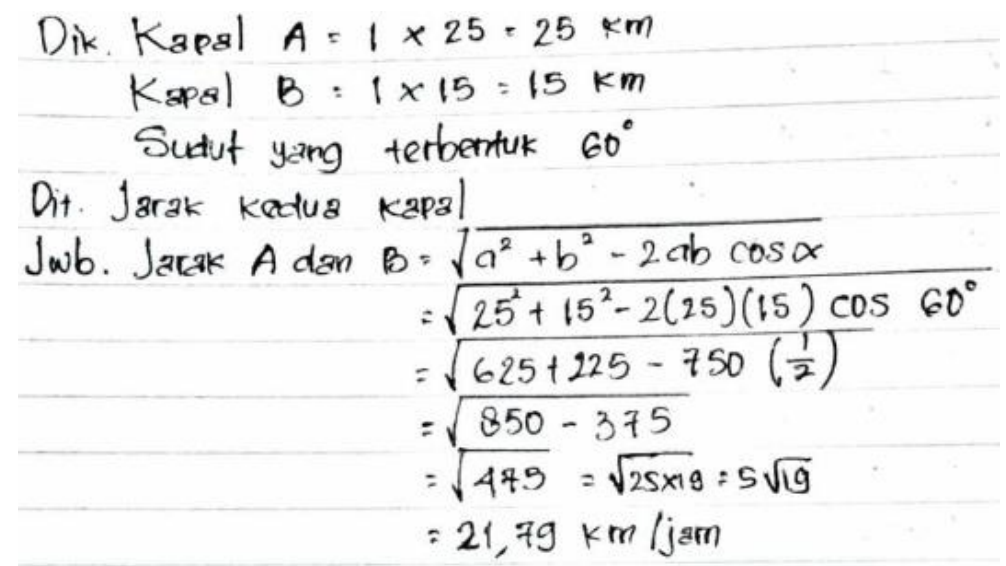

Gambar 5. Hasil Jawaban Mahasiswa VT pada soal HOTS bertipe C5

Berdasarkan Gambar 5, mahasiswa VT belum menyelesaikan permasalahan yang disajikan pada soal tipe C5. Hal ini ditunjukan dengan mahasiswa VT tidak melakukan penilaian terhadap solusi yang telah dibuat yaitu dengan memeriksa dan mengkritisi terlebih dahulu hasil yang diperoleh. Hal ini menyebabkan terjadi kesalahan memberikan satuan pada jarak antara kapal Baruna I dan Baruna II yang seharusnya $21,79 \mathrm{~km}$ tetapi yang ditulis yaitu $21,79 \mathrm{~km} / \mathrm{jam}$ yang merupakan satuan dari kecepatan. Mahasiswa VT juga tidak memberikan penilaian terhadap solusi yang telah dibuat.

Soal selanjutnya dengan level paling tinggi yaitu soal tipe C6 atau mengkreasi yaitu kemampuan merumuskan, merencanakan, memproduksi yang memadukan satu sama lain untuk membuat suatu produk yang orisinal. Menurut (Krathwohl, 2002) soal tipe C6 ini menuntut mahasiswa untuk membuat generalisasi, merancang suatu cara untuk menyelesaikan masalah dan mengorganisasikan bagianbagian menjadi struktur baru. Hal ini ditunjukan pada soal nomor 5 yang menuntut mahasiswa untuk menyelesaikan masalah dengan membuat generalisasi, merancang dan mengorganisasi.

Terdapat banyak penyelesaian yang bisa dimanfaatkan oleh mahasiswa pada soal nomor 5. Akan tetapi, hanya terdapat 4 mahasiswa yang berhasil menjawab dengan benar dan termasuk dalam kategori sangat kurang dengan presentase $15,38 \%, 20$ mahasiswa belum menjawab soal dengan tepat dan 2 mahasiswa tidak menjawab sama sekali. Hasil jawaban mahasiswa VT pada soal HOTS tipe C6 dapat dilihat pada Gambar 6. 
DOI: https://doi.org/10.24127/ajpm.v10i4.4099

$$
\begin{aligned}
& \frac{1}{1+\sqrt{2}} \times \frac{1-\sqrt{2}}{1-\sqrt{2}}=\frac{1-\sqrt{2}}{1-2} . \quad \begin{array}{l}
\text { Dengsn menggunaran prinsip teleskopik, kHz } \\
\text { daped mdihstnya sebagai: }
\end{array} \\
& =\frac{1-\sqrt{2}}{-1}-=\frac{1}{1+\sqrt{2}}+\frac{1}{\sqrt{2}+\sqrt{2}}+\frac{1}{\sqrt{3}+2}+\frac{1}{2+\sqrt{5}}+\cdots+\frac{1}{\sqrt{9 g}+10} \\
& =\sqrt{2}-1 \\
& \begin{array}{l}
\frac{1}{\sqrt{2}+\sqrt{3}}=\sqrt{3}-\sqrt{2} \\
\frac{1}{\sqrt{3}+2}=2-\sqrt{3} \\
\frac{1}{2+\sqrt{5}}=\sqrt{5}-2 \\
\frac{1}{\sqrt{59}+10}=10-\sqrt{99}
\end{array} \\
& =(\sqrt{2}-1)+(\sqrt{3}-\sqrt{2})+(2-\sqrt{3})+(\sqrt{5}-2) \ldots(10-\sqrt{99}) \\
& =10-1 \\
& =9
\end{aligned}
$$

Gambar 6. Hasil Jawaban Mahasiswa VT pada soal HOTS bertipe C6

Berdasarkan Gambar 6, mahasiswa VT telah mengorganisasikan bagian-bagian menjadi struktur baru yaitu dengan menggunakan prinsip teleskopik penjumlahan untuk menyederhanakan suatu deret. Mahasiswa VT tidak melakukan perhitungan secara manual untuk mendapatkan hasil yang diinginkan, tetapi mahasiswa VT telah merancang solusi yang akan dibuat sehingga dapat mengorganisasikan bagian-bagian penting menjadi struktur baru dan diperoleh hasil dari jumlah deretnya yaitu 9. Untuk menyelesaikan soal ini masih banyak mahasiswa yang belum mampu mengorganisasikan bagianbagian menjadi struktur baru dengan tepat. Hal ini ditunjukan pada Gambar 7 hasil jawaban mahasiswa UM pada soal HOTS bertipe C6.

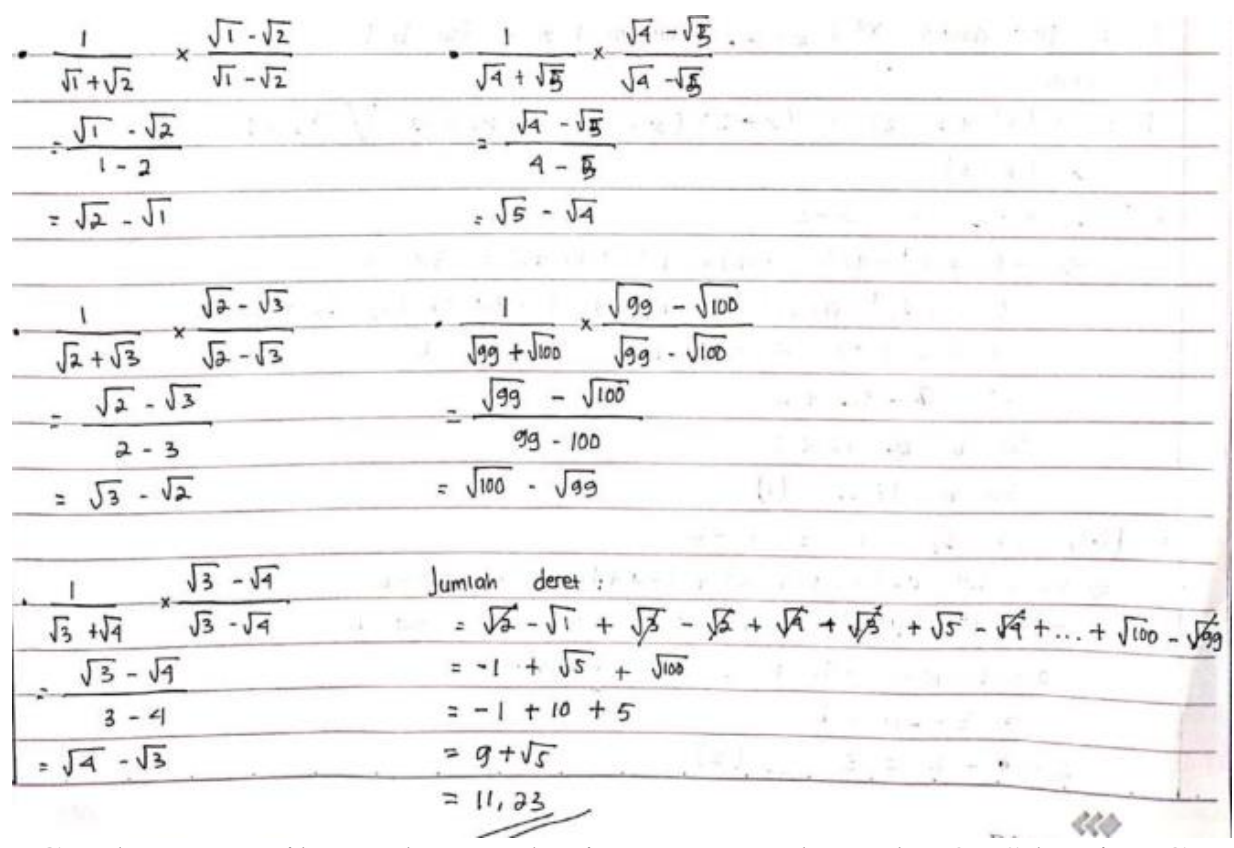

Gambar 7. Hasil Jawaban Mahasiswa UM pada soal HOTS bertipe C6 
DOI: https://doi.org/10.24127/ajpm.v10i4.4099

Berdasarkan Gambar 7, mahasiswa UM belum dapat menyelesaikan masalah dengan menggunakan cara baru untuk memperoleh hasil penyelesaian. Hal ini ditunjukan dengan masih menggunakan metode yang biasa dilakukan sehingga untuk mengorganisasikan bagian-bagian menjadi struktur baru belum dapat dilakukan.

Setelah diberikan soal tipe HOTS, terdapat beberapa faktor yang menyebabkan mahasiswa masih kesulitan dalam menyelesaikan soal HOTS, diantaranya sebagian besar mahasiswa belum memahami konsep materi dengan baik dalam menyelesaikan per masalahan dan belum terbiasa dalam menyelesaikan soal-soal tipe HOTS terkhusus untuk aspek mengkreasi. Hal ini sejalan dengan penelitian (Dosinaeng et al., 2019) yaitu masih rendahnya kemampuan mahasiswa dalam menyelesaikan masalah berorientasi HOTS terutama pada kemampuan mencipta yang pada umumnya mahasiswa masih berada pada kategori menganalisis masalah. Selanjutnya hasil penelitian (Purwanti, 2020) juga menunjukan bahwa perlu ada peningkatan kemampuan mahasiswa dalam menyelesaikan soal HOTS khususnya tipe C5 dan C6, terlihat dari kriteria yang diperoleh mahasiswa masuk dalam kriteria cukup. Maka perlu adanya evaluasi yang harus dilakukan oleh pendidik secara berkala dan berkesinambungan untuk memberikan penguatan dalam meninjau konsep yang belum dipahami mahasiswa.

. Pendidik juga perlu diberikan pelatihan untuk meningkatkan kemampuan mengajar dengan menggunakan pendekatan, strategi dan metode pembelajaran yang efektif sehingga mahasiswa dapat dengan mudah memahami konsep yang disajikan pada materi.
Implikasi dari penelitian ini adalah secara teori keterampilan HOTS dapat meningkatkan kemampuan matematis sehingga mahasiswa mampu berpikir kritis dan kreatif melalui permasalahan yang diberikan dengan tujuan untuk memacu pemahaman mahasiswa lebih mendalam. Setelah diimplementasikan kepada mahasiswa ternyata masih banyak mahasiswa yang mengalami kesulitan dalam menyelesaikan permasalahan terkhusus pada aspek mengkreasi (C6).

\section{KESIMPULAN DAN SARAN}

Hasil penelitian menunjukkan secara keseluruhan kemampuan mahasiswa dalam menyelesaikan 10 soal bertipe HOTS pada mata kuliah Kapita Selekta Matematika SMA mencapai $80,77 \%$ termasuk dalam kategori tinggi dalam mengerjakan soal tipe C4 (menganalisis) artinya mahasiswa mampu menguraikan suatu informasi terhadap suatu materi menjadi komponen-komponen yang lebih jelas. Selanjutnya diperoleh persentase sebesar 75,38\% juga termasuk dalam kategori tinggi dalam mengerjakan soal tipe C5 (mengevaluasi), artinya mahasiswa mampu melakukan penilaian atau evaluasi terhadap solusi yang disajikan sesuai standar yang ditentukan oleh mahasiswa sendiri. Terakhir diperoleh persentase sebesar 7,69\% dengan kategori sangat kurang dalam mengerjakan soal tipe C6 (mengkreasikan), artinya masih banyak mahasiswa belum mampu mengorganisasikan bagian-bagian menjadi struktur baru dengan tepat.

Untuk dapat mengembangkan kemampuan mahasiswa dalam menyelesaikan soal bertipe HOTS sebaiknya pendidik membiasakan mahasiswa dalam menggali potensinya dengan menggunakan pendekatan atau 
DOI: https://doi.org/10.24127/ajpm.v10i4.4099

strategi pembelajaran sehingga mahasiswa dapat memahami konsep yang belum dipahami.

Saran untuk peneliti lain agar dapat melakukan penelitian lebih mendalam untuk menemukan faktor penyebab dan solusi untuk melihat kemampuan mahasiswa dalam menyelesaikan soal bertipe HOTS.

\section{DAFTAR PUSTAKA}

Abdullah, A. H., Abidin, N. L. Z., \& Ali, M. (2015). Analysis of students' errors in solving Higher Order Thinking Skills (HOTS) problems for the topic of fraction. Asian Social Science, 11(21), 133142.

https://doi.org/10.5539/ass.v11n21 p133

Anderson, L. W., Krathwohl, D. R., \& Bloom, B. S. (2001). A taxonomy for learning, teaching, and assessing: a revision of Bloom's taxonomy of educational objectives. $41(4), \quad 352$. http://books.google.com/books?id= JPkXAQAAMAAJ\&pgis $=1$

Apino, E., \& Retnawati, H. (2017). Developing Instructional Design to Improve Mathematical Higher Order Thinking Skills of Students. IOP Conf. Series: Journal of Physics 812.

Awaliyah, S. (2018). Penyusunan soal hots bagi guru ppkn dan ips sekolah menengah pertama. Jurnal Praksis Dan Dedikasi Sosial, 1(1), 46-53.

Bona, M. F. (2018). Indonesia Darurat Matematika. Berita Satu. Berita Satu.

https://www.beritasatu.com/nasion al/521939-indonesia-daruratmatematika

Brookhart, S. M. (2010). How to assess higher-order thinking skills in your classroom. United States of Amerika: ASCD Member Book.

Budiman, A., \& Jailani, J. (2014). Pengembangan Instrumen

Asesmen Higher Order Thinking Skill (Hots) Pada Mata Pelajaran Matematika Smp Kelas Viii Semester 1. Jurnal Riset Pendidikan Matematika, 1(2), 139-151.

https://doi.org/10.21831/jrpm.v1i2. 2671

C. Chinedu C., \& Kamin, Y. (2015). Strategies for improving higher order thinking skills in teaching and learning of design and technology education. Journal of Technical Education and Training (JTET), 7(2), 35-43.

Churches, A. (2007). Bloom's Digital Technology. 1-11. http://www.ccconline.org/wpcontent/uploads/2013/11/Churches _2008_DigitalBloomsTaxonomyG uide.pdf

Destiniar, Mulbasari, A. S., Fuadiah, N. F., Octaria, D., Ningsih, Y. L., Retta, A. M., \& Isroqmi, A. (2020). Pelatihan Penyusunan Soal HOTS Untuk Mengembangkan Kemampuan Pedagogik Guru. Jurnal Pengabdian Kepada Masyarakat, 4 (1). http://ejurnal.ikippgribojonegoro.a c.id/index.php/J-ABDIPAMAS

Dinni, H. N. (2018). HOTS ( High Order Thinking Skills ) dan Kaitannya dengan Kemampuan Literasi Matematika. Prisma, 1, 170-176.

Dosinaeng, W. B. N., Leton, S. I., \& Lakapu, M. (2019). Kemampuan Mahasiswa dalam Menyelesaikan Masalah Matematis Berorientasi HOTS. JNPM (Jurnal Nasional Pendidikan Matematika), 3(2), 250. 
DOI: https://doi.org/10.24127/ajpm.v10i4.4099

https://doi.org/10.33603/jnpm.v3i2 .2197

Effendi, R. (2017). Konsep Revisi

Taksonomi Bloom Dan

Implementasinya Pada Pelajaran

Matematika Smp. JIPMat, 2(1).

https://doi.org/10.26877/jipmat.v2i 1.1483

Forehand, M. (2005). Bloom's taxonomy: Original and revised. In $M$. Orey $(E d)$. Emerging perspectives on Learning, teaching, and technology. http://projects.coe.uga.edu/epltt/

Hadi, S., \& Novaliyosi. (2019). TIMSS Indonesia (Trends in International Mathematics and science study). Prosiding Seminar Nasional \& Call For Papers, 562-569.

Krathwohl, D. R. (2002). A revision of Bloom's Taxonomy: an overviewTheory Into Practice, College of Education (Vol. 41, Issue 4). The Ohio State University.

Listiani, W., \& Sulistyorini, Y. (2020). The Ability of Students as Teacher Candidates in Developing Higher Order Thinking Skills Mathematics Test. International Journal of Education and Research, 8(9), 87100.

Ngalim, M., \& Purwanto. (2012). Prinsip-prinsip dan teknik pengajaran. Bandung: PT Remaja Rosdakarya.

Prasetyo, H. (2020). Kemampuan Matematika Siswa Indonesia Berdasarkan TIMSS. Jurnal Pedagogik, 3(2), 111-117.

Purwanti, S. (2020). Analisis kemampuan mahasiswa dalam menyelesaikan soal IPA tipe HOTS. Jipva, 4, 93-101. http://ejournal.ivet.ac.id/index.php/jipva

Sangpom, W., Suthisung, N., Kongthip, Y., \& Inprasitha, M. (2016). Advanced Mathematical Thinking

and Students' Mathematical Learning: Reflection from Students' Problem-Solving in Mathematics Classroom. Journal of Education and Learning, 5(3), 72.

https://doi.org/10.5539/jel.v5n3p72 Siswono, T. Y. E. (2018). Pembelajaran Matematika Berbasis Pengajuan dan Pemecahan Masalah. Bandung: Remaja Rosdakarya.

Suryapuspitarini, B. K., Wardono, \& Kartono. (2018). Analisis SoalSoal Matematika Tipe Higher Order Thinking Skill ( HOTS ) pada Kurikulum 2013 untuk Mendukung Kemampuan Literasi Siswa. Prisma, Prosiding Seminar Nasional Matematika, 1, 876-884. https://journal.unnes.ac.id/sju/inde x.php/prisma/article/view/20393

Tanujaya, B., \& Mumu, J. (2020). Students' misconception of HOTS problems in teaching and learning of mathematics. Journal of Physics: Conference Series, 1657(1), 0-6. https://doi.org/10.1088/17426596/1657/1/012081

Tanujaya, B., Mumu, J., \& Margono, G. (2017). The Relationship between Higher Order Thinking Skills and Academic Performance of Student in Mathematics Instruction. International Education Studies, 10(11), 78. https://doi.org/10.5539/ies.v10n11 p78

Wicasari, B., \& Ernaningsih, Z. (2016). Analisis Kemampuan Berpikir Siswa dalam Menyelesaikan Permasalahan Matematika yang Berorientasi Pada HOTS. Seminar Nasional Reforming Pedagogy, 249-254.

Wulandari, S., Hajidin, H., \& Duskri, M. (2020). Pengembangan Soal 
DOI: https://doi.org/10.24127/ajpm.v10i4.4099

Higher Order Thinking Skills (HOTS) pada Materi Aljabar di Sekolah Menengah Pertama. Jurnal Didaktik Matematika, 7(2), 200-220.

https://doi.org/10.24815/jdm.v7i2. 17774

Yee, M. H., Yunos, J. Md., Othman, W., Hassan, R., Tee, T. K., \& Mohamad, M. M. (2015). Disparity of Learning Styles and Higher Order Thinking Skills among Technical Students. Procedia Social and Behavioral Sciences, 204(November 2014), 143-152. https://doi.org/10.1016/j.sbspro.20 15.08.127

Yen, T. S., \& Halili, S. H. (2015). Effective Teaching of HigherOrder Thinking (HOT) in Education. The Online Journal of Distance Education and ELearning, 3(2), 41-47. 